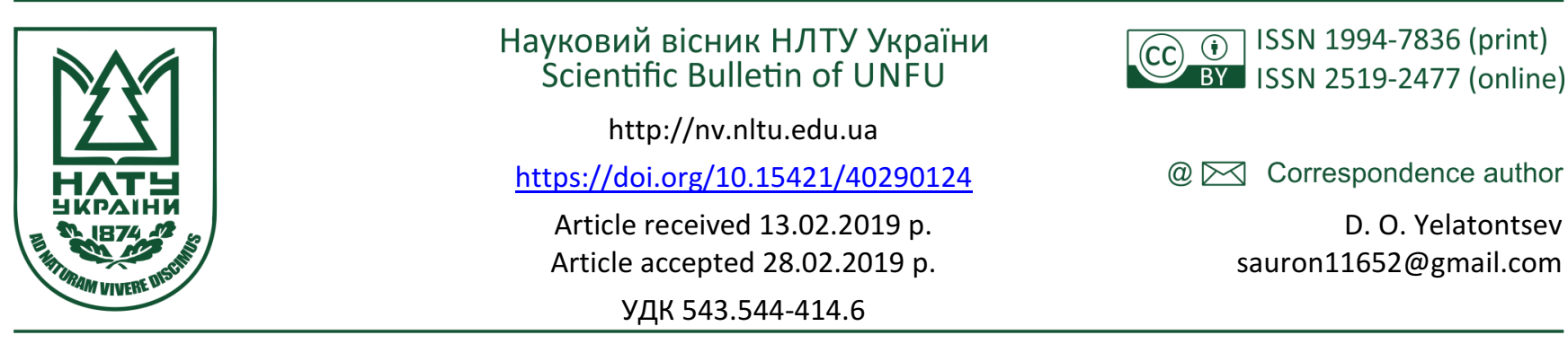

Д. О. Єлатонцев ${ }^{1}$, А. П. Мухачев ${ }^{2}$, В. І. Супрунчук ${ }^{3}$

${ }^{1}$ Дніпровський державний технічний університет, м. Кам'янське, Украйна

${ }^{2}$ ТзОВ науково-інноваиійне підприємство "ДІЯ", м. Кам'янське, Україна

${ }^{3}$ Наиіональний технічний університет Украйни "Київський політехнічний інститут ім. Ігоря Сікорського", м. Київ, Украйна

\title{
СОРБЕНТ ЛІГНОЦЕЛЮЛОЗНИЙ ЗІ ШКАРАЛУПИ ВОЛОСЬКОГО ГОРІХА
}

Підвищити ефективність сорбційних методів очищення стічних та природних вод можна за рахунок розробки недорогих сорбентів, селективних до відповідних полютантів. 3 огляду на це, найбільш оптимальною сировиною для отримання дешевих адсорбентів, які не потребують регенерації, варто вважати лігнін-целюлозовмісні сільськогосподарські відходи (наприклад шкаралупа волоського горіха). Очищення стічних вод за допомогою дешевих біосорбентів на основі лігніну і целюлози характеризується ефективністю вилучення токсикантів із розчинів, простою технологією виготовлення сорбентів, використанням стандартного устаткування. Усе це дає змогу істотно знизити загальну вартість очищення води. Тому розроблення нових ефективних і дешевих сорбційних матеріалів на основі лігніну і целюлози, з метою розширення сфер їх застосування та ефективності використання для вилучення металів, радіонуклідів, солей і інших забруднювачів, $є$ актуальним завданням. Обгрунтовано доцільність утилізації багатотоннажних відходів харчової промисловості у виробництві сорбентів для очищення забруднених природних і стічних вод. На основі аналізу фахових та патентних джерел, за період з 1997 по 2018 рр., розглянуто технологічні параметри процесів фосфорилювання під час виробництва сорбентів лігноцелюлозних (СЛЦ) зі шкаралупи волоського горіха. Вивчено вплив температури, концентрації робочих розчинів, тривалості оброблення сировини, відношення тверда фаза: розчин на ефективність процесу отримання сорбційного матеріалу. Запропоновано новий енерго-ресурсозберігаючий спосіб виробництва СЛЦ, який мінімізує обсяг утворення стічних вод і забезпечує отримання сорбенту високої якості.

Ключові слова: лігнін; целюлоза; фосфорилювання; технологічні параметри; шкаралупа горіха; сорбція.

Вступ. Сільське господарство, харчова та переробна промисловість - найрозвиненіші галузі матеріального виробництва України, є одночасно найбільшими джерелами утворення твердих відходів: тільки кісточок абрикосу і шкаралупи горіхів щорічно утворюється 100120 тис. т (Bondar, 2017). Частину відходів агропромислового комплексу використовують як сировину для виробництва широкого спектра цінних продуктів: кормів для худоби, добрив, палива, а також для продуктів екологічного, медичного i харчового призначення. Але значну частку таких відходів не утилізують, а вивозять на звалища, створюючи цим самим значну екологічну проблему. Використання сорбентів на основі вторинної сировини харчових i сільськогосподарських підприємств допоможе вирішити актуальні екологічні проблеми - ресурсозбереження і забезпечення природної рівноваги в навколишньому середовищі.

Доцільність використання природних рослинних біополімерів як вихідної сировини для виробництва сорбенту лігноцелюлозного (СЛЦ) зумовлюється такими чинниками (Kovalenko et al., 2017):

- біологічною сумісністю і безпекою;
- особливостями будови, що спрощує механічну і термічну обробку та здатність вступати в хімічні реакції (приєднання, заміщення, комплексоутворення, іонного обміну тощо);

- практичною необмеженістю і дешевизною сировинної бази;

- наявністю в Україні достатнього технічного і технологічного потенціалу для виробництва сорбентів промислового та екологічного призначення.

Джерелами таких матеріалів $є$ тверді відходи харчової та переробної промисловості - шкаралупа горіхів, кісточки абрикосу, персику, сливи, вишні; лушпиння зернових культур, качани кукурудзи тощо. Основними складовими компонентами цих відходів є целюлоза i лігнін, фібрилярна будова котрих забезпечує матеріалу розвинену пористу структуру (Varghese et al., 2018).

Мета роботи полягає в аналізі наукових фахових джерел, в яких описано технології виробництва СЛЦ, виявлено переваги та недоліки кожної з них і обгрунтовано найбільш технологічно раціональний і екологічно прийнятний спосіб фосфорилювання лігноцелюлозовмісної сировини - шкаралупи волоського горіха.

Викладення основного матеріалу. У хімічному складі шкаралупи волоського горіха (Júglans régia) переважає лігнін (37-47\%), а також целюлоза (31-41\%).

\section{Інформація про авторів:}

Єлатонцев Дмитро Олександрович, асистент, кафедра хімічної технології неорганічних речовин. Email: sauron11652@gmail.com; https://orcid.org/0000-0003-1043-418X

Мухачев Анатолій Петрович, канд. фіз.-мат. наук, заступник директора. Email: map45@ukr.net

Супрунчук Володимир Ілліч, канд. хім. наук, доцент, кафедра технології неорганічних речовин, водоочищення та загальної хімічної технології. Email: olenalvanyuk@ukr.net; https://orcid.org/0000-0002-1148-6451

Цитування за ДСту: Єлатонцев Д. О., Мухачев А. П., Супрунчук В. І. Сорбент лігноцелюлозний зі шкаралупи волоського горіха. Науковий вісник НЛтУ України. 2019, т. 29, № 1. С. 100-115.

Citation APA: Yelatontsev, D. O., Mukhachev, A. P., \& Suprunchuk, V. I. (2019). Lignocellulosic Sorbent Derived from Walnut Shell. Scientific Bulletin of UNFU, 29(1), 100-115. https://doi.org/10.15421/40290124 
Решту становлять, відповідно, геміцелюлоза ( 13\%) і золисті речовини ( $5 \%$ ) (Nikolaichuk et al., 2007; Коvalchuk et al., 2018). Тому цей тип рослинних відходів вважають особливо перспективним для виробництва СЛЦ.

У необробленому вигляді целюлоза і лігнін, зв'язані в біополімерні комплекси, характеризуються низькими сорбційними та іонообмінними властивостями. Хх статична обмінна ємність (СОЄ) відносно $d$-металів становить 0,05 мг-екв/г, що зумовлюється низьким вмістом вільних функціональних груп, здатних до іонного обміну і комплексоутворення. Найбільш характерними функціональними групами лігноцелюлозних матеріалів $\epsilon$ метоксильні - $\mathrm{OCH}_{3}$ (до $22 \%$ ), карбоксильні - $\mathrm{COOH}$ (до $16 \%$ ), карбонільні $=\mathrm{CO}$ (до $7 \%$ ), гідроксильні (спиртові та фенольні) - ОН (до $11 \%$ ) (Nikolaichuk et al., 2007).

Лігнін є клубкоподібний, термопластичний полімер сітчастої структури. Низькомолекулярний лігнін є нерозчинним, і його надзвичайно важко виділити з полімерних структур рослин у чистому вигляді без низькомолекулярних і полімерних домішок. Органічна складова становить 78-97 \% сухої речовини. Середня молекулярна маса лігніну залежить від виду сировини і способу іiі вилучення та знаходиться в інтервалі 80011000 a.o.м. (Nikolaichuk et al., 2007). Целюлоза - це природний лінійний полісахарид, який відіграє у рослин роль каркасу. Просторова структура полісахаридів природної целюлози непориста, що практично унеможливлює молекулярну сорбцію (Varghese et al., 2018).

Підвищити сорбційну активність лігніну та целюлози можна способом відповідного хімічного модифікування кислотами, лугами, оксидами тощо (Varghese et al., 2018). Внаслідок такого оброблення матеріали набувають високої реакційної здатності, легко вступають в реакції приєднання і заміщення, можуть виконувати функції селективних сорбентів або іонообмінників.

Подрібнену до розмірів 1-2 мм шкаралупу волоського горіха використано (Halysh et al., 2017) як вихідний матеріал для виробництва сорбційного матеріалу для поглинання екотоксикантів органічного (метиленовий синій, метиловий фіолетовий, мурексид) і неорганічного $\left(\mathrm{Fe}^{3+}, \mathrm{Cu}^{2+}\right)$ походження 3 модельних водних розчинів. Технологія передбачала обробку вихідної сировини $\mathrm{CH}_{3} \mathrm{COOH}$, а також сумішшю $\mathrm{CH}_{3} \mathrm{COOH}$ та $\mathrm{H}_{2} \mathrm{O}_{2}$ (у співвідношенні 5:1) за температури $90{ }^{\circ} \mathrm{C}$. Під час модифікування шкаралупи волоського горіха за підвищеної температури в середовищі $\mathrm{CH}_{3} \mathrm{COOH}$ відбувається гідроліз низько- та високомолекулярних полісахаридних компонентів рослинних відходів, внаслідок чого лігноцелюлозний сорбент збагачується на ароматичну складову - лігнін, вміст якого сягає 48,3\%. Окрім цього, кислотний гідроліз сприяє видаленню мінеральних компонентів. Це збільшує об'єм пор сорбенту, оскільки поглинальна здатність щодо основних (метиленовий синій, метиловий фіолетовий) та кислотного (мурексид) барвників, порівняно 3 вихідною сировиною, зростає більше ніж удвічі. Також встановлено, що використання суміші $\mathrm{CH}_{3} \mathrm{COOH}$ та $9 \% \mathrm{H}_{2} \mathrm{O}_{2}$ для модифікування шкаралупи горіха сприяє видаленню більшої частки речовини ароматичного характеру, тобто відбувається делігніфікація вихідного матеріалу, і вміст лігніну в одержаному целюлозному сорбенті знижується від $37,5 \%$ до 0,8\%. Окрім цього, спостерігаємо змен- шення виходу сорбенту до 40,2 \%, а вміст целюлози в ньому підвищується від 41,2\% до 76,8 \%. Це відбувається завдяки тому, що $\mathrm{H}_{2} \mathrm{O}_{2}$ під час модифікування за підвищеної температури частково витрачається на утворення перетанової кислоти, яка є делігніфікуючим реагентом, що окиснює лігнін і переводить його до розчину. Внаслідок такого модифікування ефективність вилучення барвників отриманим сорбентом є вищою, зростає до 60-77 \%, але сорбційна ємність відносно $\mathrm{Fe}^{3+}$ i $\mathrm{Cu}^{2+} \epsilon$ нижчою, ніж вихідна матеріалу (30-45 мг/г). Недоліком цієї технології $є$ застосування речовин $\left(\mathrm{CH}_{3} \mathrm{COOH}\right.$ та $\left.\mathrm{H}_{2} \mathrm{O}_{2}\right)$, відпрацьовані розчини котрих не мають доцільних способів утилізації, до того ж технологія потребує підвищення температури реакційної суміші.

Згідно з методикою, яку запропонували автори (Nikolaichuk et al., 2007), подрібнену лігноцелюлозовмісну біомасу нагрівають за температури $100{ }^{\circ} \mathrm{C}$ у $20 \%$ розчині $\mathrm{H}_{3} \mathrm{PO}_{4}$ протягом 3 год за співвідношення кислота: біомаса $(5: 1)$, після чого біомасу відокремлюють, промивають дистильованою водою до нейтральної реакції і висушують. На другій стадії модифікування шкаралупи волоського горіху здійснюють лужну обробку 0,5\% розчинами $\mathrm{NaOH}, \mathrm{Na}_{2} \mathrm{CO}_{3}$ або $\mathrm{K}_{2} \mathrm{CO}_{3}$ за гідромодуля 46, температури $70-100{ }^{\circ} \mathrm{C}$ і тривалості процесу 90120 хв. Отриманий продукт, що містить фосфат целюлози, має $\mathrm{CO \Theta}\left(\mathrm{Na}^{+}\right)=4,2^{ \pm 0,2}$ мг-екв/г. До недоліків цієї методики відносять значні обсяги кислих промивних вод, підвищену температуру процесу.

Подрібнення лігноцелюлозної сировини збільшує питому поверхню сорбенту та підвищує ефективність подальших стадій модифікації. Встановлено (Kovalchuk et al., 2018), що природна шкаралупа волоського горіха має об'єм адсорбційних пір $0,03 \mathrm{~cm}^{3} / \Gamma$, подрібнення сировини від 1,5-2,0 мм до 0,5-1,0 мм призводить до підвищення ефективності вилучення метиленового синього на $22 \%$ та до збільшення COC за $\mathrm{Na}^{+}$вдвічі. Модифікування горіхової шкаралупи проводили способом оброблення розчинами $\mathrm{H}_{3} \mathrm{PO}_{4}$ в колбах на водяній бані зі зворотними холодильниками для підтримки постійного значення гідромодуля на рівні 5:1. Тривалість оброблення становила 60-180 хв, концентрація кислоти 5-75\%, температура реакційної суміші $95{ }^{\circ} \mathrm{C}$. Після цього фосфорильований лігноцелюлозний продукт відфільтровували від розчину, промивали дистильованою водою до нейтральних значень $\mathrm{pH}$ промивних вод та висушували до вологості 5-6 \%. Показано, що зі збільшенням концентрації $\mathrm{H}_{3} \mathrm{PO}_{4}$ під час фосфорилюваннядо $75 \%$ і тривалості модифікування до 120 хв СО€ за $\mathrm{Na}^{+}$ сягає найбільшого значення 1,9 мг-екв/г. Максимальний ступінь вилучення метиленового синього (42,4\%) досягається під час оброблення $50 \% \mathrm{H}_{3} \mathrm{PO}_{4}$ протягом 180 хв. За результатами математичного моделювання було встановлено, що оптимальними параметрами процесу є концентрація $\mathrm{H}_{3} \mathrm{PO}_{4} 54,8 \%$ та тривалість 120 хв. Цей спосіб модифікування горіхової шкаралупи характеризується тими ж недоліками, що і попередньо розглянутий. Окрім цього, автори не дослідили вплив стабілізуючих добавок під час фосфорилювання, а ефективність вилучення іонів важких металів отриманим сорбентом залишається невідомою.

Автори (Khmylko \& Orekhova, 2012) вивчали різні модифікуючі суміші на основі мінеральних і органічних кислот, пероксиду водню та азотовмісних сполук 3 
метою надання іонообмінних властивостей лігніну, целюлозі, деревині та льнотресті. Встановлено, що оптимальною сировиною для отримання сорбентів $є$ деревина. Як азотовмісні сполуки застосовували солі амонію і фосфорної кислоти, карбамід. Їхня роль зводилася до зменшення деструктивної дії компонентів модифікувального розчину. Фосфорилювання целюлози призводить до утворення одно-, дво- та тризаміщених фосфатних груп, які формують основний обмінно-сорбційний потенціал отриманого матеріалу. Наявність карбаміду у складі робочого розчину під час фосфорилювання целюлози (або лігніну) нейтралізує деструктивну дію $\mathrm{H}_{3} \mathrm{PO}_{4}$. Внаслідок оброблення фосфорною кислотою без сечовини целюлоза забарвлюється у чорний колір і стає дуже крихкою, що свідчить про руйнування піранового кільця. У разі використання для модифікації інших кислот, окрім фосфорної, утворюються сорбенти з нижчою СОЄ. Це зумовлюється хімічними властивостями фосфорної кислоти, переважно, іiї багатоосновністю та відсутністю окиснювальних властивостей. Перераховані особливості $\mathrm{H}_{3} \mathrm{PO}_{4}$ призводять до формування у структурі сорбенту стійких фосфоровмісних складних ефірів, здебільшого фосфат-ефірних груп -PO(OH $)_{2}$. Результати, які отримали автори (Khmylko \& Orekhova, 2012) доводять, що оптимальною добавкою під час активації деревини за допомогою $\mathrm{H}_{3} \mathrm{PO}_{4}$ потрібно вважати $\mathrm{CO}\left(\mathrm{NH}_{2}\right)_{2}$, а фізико-хімічні закономірності фосфорилювання 3 великою ймовірністю можуть бути поширені й на іншу сировину з високим вмістом лігніну і целюлози матеріалу (шкаралупи волоського горіха тощо).

Технологія отримання "Фоліокс КПМ" полягає у наведеному нижче (Yerofeyev et al., 2011). Вихідний матеріал (плодову кісточку персикову, сливову або абрикосову) в суміші з сухими інгредієнтами $1 \%$ оксалату амонію; 0,1\% вуглекислого амонію; 0,5 \% щавлевої кислоти; 0,5\% цитрату амонію; 0,1 мас \% гідроксиду барію обробляють у кульовому млині протягом 24 год iз подальшим промиванням на фільтрі. На першому етапі промивають $0,5 \%$ розчином гідроксиду амонію на основі знесоленої води у співвідношенні 1:10 за нормальної температури. На другому етапі промивання ведуть $1 \%$ розчином щавлевої кислоти на основі знесоленої води. Промивання здійснюють за кімнатної температури до появи прозорого фільтрату жовтуватого кольору. Промитий продукт висушують, класифікують і відбирають фракцію 80-150 мкм.

Сировиною для виробництва сорбенту "Фоліокс" може бути будь-яка лігнін- та целюлозовмісна сировина, зокрема шкаралупа волоського горіху. Сорбент "Фоліокс" успішно застосовували (Yerofeyev et al., 2013; Kultenko \& Yerofeyev, 2015; Cherkashina et al., 2015) для вилучення радіонуклідів, іонів важких металів, нафтопродуктів, а також аніонів $\mathrm{PO}_{4}{ }^{3-}, \mathrm{NO}_{3}{ }^{-}, \mathrm{SO}_{4}{ }^{2-} \mathrm{i} \mathrm{NH}_{4}{ }^{+}$з водних розчинів.

Основу механохімічного процесу становить окисний аммоноліз, під час якого відбувається активація матриці лігніну з утворенням додаткових карбоксильних, карбонільних функціональних груп і приєднання четвертинних амонієвих угруповань. Внаслідок механохімічного процесу температура усередині кульового млина підвищується до $70-80{ }^{\circ} \mathrm{C}$, тиск газів - до 0,78 МПа, що виходять через нещільності, з різким запахом амоніаку. Перевагою способу є простота виготовлення продукту, при цьому використовують просте устаткування. Вто- ринні рідкі відходи, що утворюються на стадії промивання цільового продукту, рекомендують використовувати як розріджувач (що містить у своєму складі лігніновий перетворювач іржі) водоемульсійних фарбувальних матеріалів або як протикорозійну добавку в бетон. Основним недоліком цього методу виробництва СЛЦ є невисока економічна доцільність, зумовлена вельми тривалою механохімічною обробкою із застосуванням високовартісної знесоленої води і дефіцитних летких реагентів, а також викидами амоніаку.

Близькими за технічною сутністю до способу отримання "Фоліокс КПМ" є технології виробництва сорбентів "Фоліокс-Г" (гранульований) та САК-001 (сорбент амфоліт кісточковий).

Технологія тримання "Фоліокс-Г" (Yerofeyev et al., 1997) передбачає обробку вихідного матеріалу (плодових кісточок) послідовно $0,5-0,8 \%$ розчином $\mathrm{H}_{2} \mathrm{SO}_{4}$ за гідромодуля 1:17-15, температури 200-250 ${ }^{\circ} \mathrm{C}$ і тиску 0,98-1,18 МПа протягом 5-6 год із подальшою витримкою за гідромодуля 1:3 протягом 4-6 год за тиску 0,450,59 МПа і температури $140-150{ }^{\circ} \mathrm{C}$ сумішшю у співвідношенні 1:1:1 розчинів $20 \% \mathrm{NH}_{4} \mathrm{OH}, 0,1 \% \mathrm{NaOH}$, $0,5 \%$ цитрату натрію, 3 подальшою обробкою розчином $1 \%$ комплексону III за гідромодуля 1:5 протягом 2-3 год і температури $60-70{ }^{\circ} \mathrm{C}$ та за нормального тиску. Далі продукт промивають проточною водою до прозорого фільтрату. Готовий продукт є гранулами неправильної форми коричневого кольору, у складі яких відсутні вільні кислоти, редукуючі та смолисті речовини, гумінові і фульвокислоти.

Під час оброблення $0,5-0,8 \%$ розчином $\mathrm{H}_{2} \mathrm{SO}_{4}$ в ізотермічних умовах відбувається процес повного гідролізу полісахаридів (целюлози), пентозанів і редукуючих речовин, утворення розчинних солей лігногумінових i фульвокислот, які звільняють пори в матриці лігніну. Під час окислювального амонолізу відбувається активація матриці лігніну, утворення додаткових карбоксильних і приєднання амінних груп завдяки гідролізу спиртових груп, розриву вуглеводних і ефірних зв'язків, звільнення мікропор у разі вимивання 3 них натрієвих солей гумінових і фульвокислот, а також солей низькомолекулярних фрагментів лігніну, що значно збільшує іонообмінну і сорбційну ємність. Цитрат натрію сприяє звільненню пор і збільшенню внутрішньої поверхні сорбенту до $300 \mathrm{~m}^{2} / \Gamma$. Оброблення розчином комплексону III призводить до видалення катіонних домішок, звільненню пор лігніну та отримання якісно нового сорбенту, при цьому поліпшуються його фізико-механічні властивості та збільшується активна поверхня.

Згідно з технологією виробництва САК-001 (Yerofeyev et al., 2016), як вихідний матеріал використовують плодову кісточку (персикову, абрикосову, сливову, вишневу) i/або верхній перикарпій волоського, кедрового горіха, фундука, мигдалю. Потім цю кісточку, розмолоту і класифіковану за гранулометричним складом $(<0,35$ мм - $10 \% ; 0,36-0,55$ мм - $55 \% ; 0,56-0,75$ мм $25 \%$; 0,76-1,25 мм - $10 \%$ ), обробляють сумішшю розчинів: $0,5 \% \mathrm{NH}_{4} \mathrm{OH}, 0,5 \% \mathrm{NaOH}, 0,5 \%$ ЕДТА, у співвідношенні 1:1:1 в автоклаві за гідромодуля 1:5, температури $120-134{ }^{\circ} \mathrm{C}$ протягом 4-6 год. Потім тверду фазу відфільтровують і промивають знесоленою водою з подальшим обробленням сумішшю розчинів: $0,5 \% \mathrm{FeCl}_{3}$, $0,1 \% \quad \mathrm{NaClO}_{4}, \quad 0,5 \% \quad \mathrm{CH}_{3} \mathrm{COOH}$ у співвідношенні $1: 1: 1$ за $\mathrm{pH} 1,0-3,0$ в автоклаві в ізотермічних умовах 
упродовж 4-6 год і температури $120-140{ }^{\circ} \mathrm{C}$ та гідромодуля 1:8. Процес ведуть за $\mathrm{pH} 2-3$ в ізотермічних умовах сумішшю розчинів: $0,5 \% \mathrm{FeCl}_{3}, 0,5 \% \mathrm{NaClO}_{4}$, $0,5 \% \mathrm{CH}_{3} \mathrm{COOH}$ у співвідношенні $1: 1: 1$, за гідромодуля $1: 10$, температури $140-150{ }^{\circ} \mathrm{C}$ і часу процесу 4-6 год.

Під час лужного гідролізу й окислювального амонолізу відбувається гідроліз із розривом алкіларільних ефірних зв'язків у лінійному ланцюзі структурного фрагмента лігніну з утворенням метиленхінонів, які стабілізуються або $\beta$-протоном, або $\gamma$-метильною групою. Одночасно відбувається утворення додаткових карбоксильних груп за рахунок гідролізу спиртових груп, збільшуючи кількість хінонметильних і вільнорадикальних утворень, які сприяють підвищенню реак- ційної здатності лігніну. Внаслідок окисного амонолізу і комплексоутворення в окисно-відновній системі утворюється цвіттер-макромолекула лігніну з проявом катіонно-аніонообмінних властивостей (амфоліт) залежно від рН і складу середовища. Спільними недоліками технологій одержання сорбентів "Фоліокс-Г" та САК-001 є застосування дорогих та дефіцитних реактивів, значна складність апаратурного та технічного оформлення процесу, утворення стічних вод, забруднених багатьма шкідливими компонентами. Технологія виробництва САК-001 додатково ускладнена необхідністю ведення процесу в автоклаві.

Порівняння основних фізико-хімічних властивостей модифікацій сорбенту "Фоліокс" надано у табл. 1.

Табл. 1. Фізико-хімічні характеристики модифікацій сорбенту "Фоліокс"

\begin{tabular}{|c|c|c|c|}
\hline Показник & "Фоліокс КПМ" & "Фоліокс-Г" & CAK-001 \\
\hline Зовнішній вигляд & $\begin{array}{l}\text { порошок світло-ко- } \\
\text { ричневого кольору }\end{array}$ & $\begin{array}{c}\text { гранули неправильної } \\
\text { форми, коричневого } \\
\text { кольору з пористою } \\
\text { поверхнею }\end{array}$ & $\begin{array}{c}\text { гранули неправильної } \\
\text { форми, темно-коричневого } \\
\text { кольору пористої структу- } \\
\text { ри } \\
\end{array}$ \\
\hline $\begin{array}{l}\text { Гранулометричний склад: } \\
\text { розмір зерен, мкм; } \\
\text { вміст робочої фракції, \% не менше; } \\
\text { ефективний розмір зерен, мкм; } \\
\text { коефіцієнт однорідності, не більше }\end{array}$ & $\begin{array}{l}80-150 \\
95 \\
200 \\
2,5\end{array}$ & $\begin{array}{c}310-1250 \\
90 \\
700 \\
2,5\end{array}$ & $\begin{array}{c}350-1200 \\
* \\
* \\
*\end{array}$ \\
\hline Вміст вологи, \% & $65-75$ & $65-75$ & $*$ \\
\hline $\begin{array}{l}\text { Питомий об'єм, см }{ }^{3} / \Gamma \text { не більше: } \\
\text { а) у Н-формі; } \\
\text { б) у } \mathrm{NH}_{4} \text {-формі }\end{array}$ & $\begin{array}{c}1,7 \\
1,85\end{array}$ & $\begin{array}{l}2,5-2,8 \\
2,9-4,8\end{array}$ & 1,656 \\
\hline Питома поверхня, м²/г не менше & 750 & 300 & 408 \\
\hline $\begin{array}{l}\text { Повна статична обмінна ємність по Ва }(\mathrm{OH})_{2} \\
\Gamma-е к в / \text { дм }^{3} \text { не менше }\end{array}$ & 4,6 & 3,7 & 3,8 \\
\hline $\begin{array}{l}\text { Функціональні групи, мг-екв/г: } \\
\text { а) кислі ОН групи (-СООН; ОН-фенольні); } \\
\text { б) карбоніли =СО; } \\
\text { в) спиртові гідроксили -ОН; } \\
\text { г) зв'язаний азот }\end{array}$ & $\begin{array}{l}15,05 \\
1,58 \\
4,05 \\
3,99\end{array}$ & $\begin{array}{c}14,56 \\
1,44 \\
3,78 \\
3,81\end{array}$ & $\begin{array}{c}13,64 \\
1,64 \\
3,74 \\
2,42\end{array}$ \\
\hline
\end{tabular}

Примітка: * дані відсутні.

Автори пропонують використовувати сорбенти "Фоліокс" для очищення промислових і стічних вод від органічних та неорганічних компонентів, питної води від важких металів і радіонуклідів, технологічних середовищ хімічної, коксохімічної та нафтогазової промисловості від токсичних полютантів, технологічних середовищ атомної енергетики та ядерно-паливного циклу від радіонуклідів і трансуранових елементів, а також під час очищення газоповітряних середовищ від альфа-, бета-аерозолів.

Серед інших технологій виробництва сорбційних та іонообмінних матеріалів із целюлозовмісної сировини особливу увагу привертають наступні.

Спосіб отримання сорбенту (Savvateeva \& Kamenev, 2001), що містить дроблення шкаралупи горіхів до шматків розміром 1х1,5 cм, імпрегнування і обробку до утворення сорбційної вуглецевої поверхні. Операції імпрегнування i оброблення шкаралупи поєднують i здійснюють спочатку способом витримування іiї в розчині концентрованої $\mathrm{HCl}$ протягом 15-30 год, потім після промивання водою до нейтрального $\mathrm{pH}$ витримують шкаралупу в $33 \% \mathrm{NaOH}$ протягом 2-2,5 год, промивають до нейтрального $\mathrm{pH}$, подрібнюють і сушать за температури $100{ }^{\circ} \mathrm{C}$. На думку авторів, поєднання операцій імпрегнування і оброблення дає змогу підвищити ефективність імпрегнування, пом'якшити процес карбонізації та знизити енерговитрати. Спосіб дає змогу отримати оригінальний продукт із відходів виробництва, який має питому поверхню $4500 \mathrm{~m}^{2} / \Gamma$, сумарний об'єм пор
$1,15-1,37 \mathrm{~cm}^{3} / \Gamma$, за виходу сорбенту 75-82 \%. Недоліками способу є застосування вельми леткої та корозійно активної концентрованої $\mathrm{HCl}$, значна тривалість процесу, великі обсяги стічних вод, забруднених хлоридами. У цьому способі, на відміну від усіх інших, операції делігніфікації та кислотної активації сировини змінені місцями, а готовий сорбент пропонують застосовувати для вилучення радіоактивного Йоду (вилучення до 5 \%) i бактерій Staphylococcus aureus (бактерицидна дія 4,2-

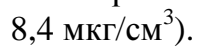

Згідно з іншим способом (Osadchenko et al., 2007), природний полімер у вигляді шкаралупи горіхів (волоських, фундук) подрібнюють до частинок розміром до 10 мм, обробляють сумішшю кислот $\mathrm{CH}_{3} \mathrm{COOH}$ i $\mathrm{HNO}_{3}$ під час нагрівання на киплячій водяній бані протягом 1,5-2,0 год, промиванні і сушінні поетапно: при температурах $60-65{ }^{\circ} \mathrm{C}, 100-105{ }^{\circ} \mathrm{C}$ i $125-130{ }^{\circ} \mathrm{C}$ до постійної маси, подрібнення, відбору частинок розміром не більше 3 мм. Оптимальне співвідношення $80 \%$ $\mathrm{CH}_{3} \mathrm{COOH}$ i 55-65 \% $\mathrm{HNO}_{3}$ становить 9,5-10:1. Тривалість сушіння за $60-65{ }^{\circ} \mathrm{C}$ і $100-105^{\circ} \mathrm{C} 1-2$ години, за $125-130^{\circ} \mathrm{C}$ - до постійної маси. Готовий сорбент має СО€ по $\mathrm{Cu}^{2+} \mathrm{i} \mathrm{Cd}^{2+} 2,0-3,5$ мг/Г (вихід сорбенту 68$70 \%$ ). Виконання цієї технології ускладнене поетапним сушінням, утворенням значних обсягів корозійно активних промивних вод.

За способом виробництва сорбенту на основі фосфорильованого лігніну (Bykov \& Ershov, 2009), який застосовували, зокрема, для вилучення іонів $\mathrm{UO}_{2}{ }^{2+} \mathrm{Ta} \mathrm{Cu}^{2+}$, 
зразки лігніну попередньо просочувалися за $80{ }^{\circ} \mathrm{C}$ водним розчином, що містив $\mathrm{H}_{3} \mathrm{PO}_{4}$ i $\mathrm{CO}\left(\mathrm{NH}_{2}\right)_{2}$ за гідромодуля 1:10 протягом 1 год. За температури, вищій за 80 ${ }^{\circ} \mathrm{C}$, карбамід у водному розчині розкладається до карбамату амонію. Потім просочені зразки висушували і піддавали фосфорилюванню, прогрівали протягом 1 год за $145{ }^{\circ} \mathrm{C}$ і промивали гарячою водою та розчином $0,1 \mathrm{M}$ $\mathrm{HCl}$.

Автори встановили, що оптимальною температурою прогрівання просоченого лігніну є $145^{\circ} \mathrm{C}$ тривалістю 1 год; максимальна кількість (4,8 мг-екв/г) кислотних груп імпрегнується на поверхню лігніну за концентрації $\mathrm{H}_{3} \mathrm{PO}_{4} 1,5$ моль/дм ${ }^{3}$ та концентрації $\mathrm{CO}\left(\mathrm{NH}_{2}\right)_{2} \quad 2,8$ моль/дм ${ }^{3}$. Показано, що фосфорилювання у присутності карбаміду збільшує вміст Фосфору в сорбенті від 2,3\% мас. до $16,6 \%$ мас. У таких умовах карбамід розкладається до амоніаку і ціанової кислоти HOCN, котра, будучи дуже реакційно здатною, швидко полімеризується до ціанурової кислоти, яка взаємодіє з лігніном у кислому середовищі за реакцією (рис. 1).

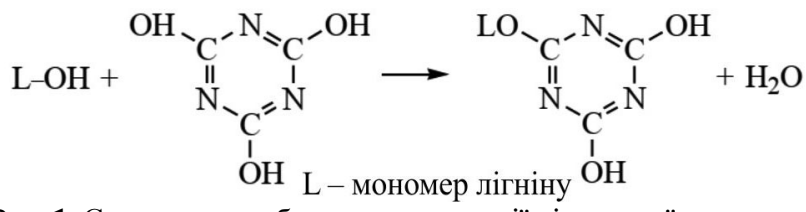

Рис. 1. Схематичне зображення взаємодії ціанурової кислоти з лігніном (Bykov \& Ershov, 2010)

Автори вважають, що фосфорилювання лігніну відбувається за участі фенольних груп -OH і карбонільних груп =CO молекул лігніну. Загалом запропонований (Bykov \& Ershov, 2009; Bykov \& Ershov, 2010) спосіб можна вважати найбільш технологічно обгрунтованим.

Внаслідок фосфорилювання целюлози можуть утворюватися дві різні форми полісахариду (рис. 2), залежно від стехіометричного співвідношення целюлоза: $\mathrm{H}_{3} \mathrm{PO}_{4}-$ у разі надлишку кислоти переважає структура 2 , і навпаки.<smiles>O=P(O)(OCl)OCl</smiles>

a)

Рис. 2. Схематичне зображення структури фосфорильованої целюлози (Suflet, Chitanu \& Popa, 2006): а) структурна форма 1; б) структурна форма 2; Cel - мономер целюлози

Автори (Suflet et al., 2006) вважають, що реакційна здатність структури 1 целюлози буде вищою.

На основі критичного аналізу описаних вище технологій отримання лігноцелюлозних сорбційних матеріалів, беручи до уваги їхні недоліки, розроблено вдосконалений енерго-ресурсозберігаючий спосіб виробництва СЛЦ зі шкаралупи волоського горіха. Спосіб містить такі основні технологічні операції:

1. Подрібнення вихідної сировини, класифікація і відбір фракції розміром 0,6-1,6 мм, що забезпечить оптимальні показники питомого об'єму, насипної густини та питомої поверхні.

2. Оброблення розчином $20 \% \mathrm{NH}_{4} \mathrm{OH}$ протягом 4 год під час постійного перемішування. Відпрацьований розчин лугу відфільтровують з метою використання у наступних циклах виробництва СЛЦ. Тверду фазу промивають водопровідною водою до $\mathrm{pH}=7-8$ (на відміну від усіх відомих аналогів, відпрацьовану воду направляють на відмивку СЛЦ від залишків $\mathrm{H}_{3} \mathrm{PO}_{4}$ на наступній стадіï) і висушують за температури $130{ }^{\circ} \mathrm{C}$ протягом 3 год.

Оброблення розчином лугу або водним розчином амоніаку шкаралупи волоського горіха підвищує розчинність меланоїдного компоненту, а також призводить до розщеплення нерозчинного комплексу біополімерів із виділенням водорозчинних полісахаридів. Вилучення водо- і лужнорозчинних речовин із сировини дає змогу функціональним групам лігніну стати більш доступними для іонів важких металів, що інтенсифікує процеси хемосорбції.

3. Оброблення кислотно-сольовим робочим розчином, який містить $20 \% \mathrm{H}_{3} \mathrm{PO}_{4}, 40 \% \mathrm{CO}\left(\mathrm{NH}_{2}\right)_{2} \mathrm{i} 40 \% \mathrm{H}_{2} \mathrm{O}$, під час постійного перемішування протягом 4 год. Таке співвідношення компонентів робочого розчину є максимально ефективним і дає змогу проводити активацію сировини зак кімнатної температури $-15-25^{\circ} \mathrm{C}$, на відміну від відомих аналогів (Nikolaichuk et al., 2007; Bykov \& Ershov, 2009; Halysh et al., 2017; Kovalchuk et al., 2018), які передбачають проведення активації за підвищених температур у діапазоні $90-150{ }^{\circ} \mathrm{C}$. Після активації суміш знову фільтрують, відділяючи фільтрат в окрему ємність, а сорбент кондиціонують способом витримки у воді протягом 6 діб. Потім воду повертають на промивку сорбенту від лугу, а готовий сорбент висушують до потрібної вологості.

Внаслідок оброблення сировини робочим розчином утворюється фільтрат, що містить $\mathrm{H}_{3} \mathrm{PO}_{4}, \mathrm{CO}\left(\mathrm{NH}_{2}\right)_{2}$, $\mathrm{H}_{2} \mathrm{O}$ та продукти їх взаємодії (зокрема фосфати амонію), а також незначну частку речовин, що вимиваються $з$ каркасу сорбенту (целюлоза, лігнін тощо). Цю рідину можна використати як рідке комплексне добриво після нейтралізації залишкової кислотності до рН 6-7 (наприклад відпрацьованим розчином після другого циклу делігніфікації або рідким амоніаком).

Отже, запропонована технологія виробництва СЛЦ, на відміну від відомих аналогів, є замкненим водооборотним циклом, причому всі стадії процесу проводяться за кімнатної температури за стандартних умов без підвищеного тиску. Основні характеристики СЛЦ наведено в табл. 2.

Табл. 2. Основні фізико-хімічні характеристики СЛЦ

\begin{tabular}{|l|c|}
\hline \multicolumn{1}{|c|}{ Показник } & Значення \\
\hline СОС, ммоль/см & 1,3 \\
\hline рН фільтрату & 7,2 \\
\hline Масова частка вологи, \% & 31,4 \\
\hline $\begin{array}{l}\text { Питомий об'єм у разі набухання у дистильованій } \\
\text { воді, см } 3 \text { /г }\end{array}$ & 0,6 \\
\hline Вихід сорбенту, \%. & 90 \\
\hline
\end{tabular}

За своїми властивостями СЛЦ наближається до слабкокислотних катіонітів i, будучи на порядок дешевшим за них, може вважатись їх доступним аналогом. СЛЦ можна використовувати для ефективного очищення промислових технологічних середовищ і стічних вод від органічних і неорганічних домішок, важких металів і радіонуклідів. Продукт можна використати на промислових намивних фільтрах, відцентрових екстракторах тощо, для очищення технологічних середовищ хімічної, коксохімічної і нафтохімічної промисловості, а також для очищення технологічних середовищ від радіонуклідів і трансуранових елементів підприємств ядерно-паливного циклу.

\section{Висновки:}

1. Критичний аналіз методів отримання лігноцелюлозних сорбентів показав, що відомі технології мають істотні недоліки (підвищені температура, тиск, складність тех- 
нологічних стадій, використання високовартісних та дефіцитних реагентів, продукування значних обсягів стічних вод), що значно обмежує їхні сфери застосування.

2. Показано, що під час використання $20 \% \mathrm{NH}_{4} \mathrm{OH}$ для делігніфікації сировини та робочого розчину для фосфорилювання, який складається $320 \% \mathrm{H}_{3} \mathrm{PO}_{4}, 40 \%$ $\mathrm{CO}\left(\mathrm{NH}_{2}\right)_{2}$ i $40 \% \mathrm{H}_{2} \mathrm{O}$, досягається СО€ 1,3 ммоль/см ${ }^{3}$ за виходу сорбенту $90 \%$.

\section{Перелік використаних джерел}

Bondar, O. I. (2017). National report on the state of the environment in Ukraine in 2015. Kyiv: Ministerstvo ekolohii ta pryrodnykh resursiv Ukrainy. [In Ukrainian].

Bykov, G. L., \& Ershov, B. G. (2009). Sorption of uranyl ions on phosphorylated lignin. Radiochemistry, 51(3), 292-294. https://doi.org/10.1134/S1066362209030138

Bykov, G. L., \& Ershov, B. G. (2010). A sorbent based on 83(2), 316-319. https://doi.org/10.1134/S1070427210020254

Cherkashina, N. I., Cherkashin, A. S., \& Maronchuk, I. I. (2015). Wastewater treatment from metal ions by sorbents from natural materials based on lignin. Technical sciences, 11-12(45-46), 51-57.

Halysh, V., Pasalskyi, B., \& Sevastianova, O. (2017). Highly effective sorbents from products after processing agriculture raw materials. Tovary i rynky, 1, 80-89. [In Ukrainian].

Khmylko, L. I., \& Orekhova, S. E. (2012). Sorbents based on lignin and cellulose-containing materials. Sviridovskie chteniia, 8, 232238. [In Russian].

Kovalchuk, A., Pochechun, T., Halysh, V., \& Trus, I. (2018). Fosforyliuvannia shkaralup voloskykh horikhiv dlia pidvyshchennia efektyvnosti ochyshchennia vodnykh rozchyniv. Tekhnichni nauky ta tekhnolohii, 2, 236-244. https://doi.org/10.25140/2411-53632018-2(12)-236-244

Kovalenko, O. O., Novoseltseva, V. V., \& Kovalenko, N. O. (2017). Waste of processing of agricultural production and production of phosphorylated lignin. Russian Journal of Applied Chemistry, [In Russian].

food products as effective filtering materials for wastewater treatment with ions of heavy metals. Voda: hyhyena y ekolohyia, 14(5), 59-66. [In Ukrainian].

Kultenko, E. A., \& Yerofeyev, V. A. (2015). Purification of industrial wastewater filtering materials on the basis of fruit pits. Energosberezhenie $i$ vodopodgotovka, 2(94), 22-24. [In Russian].

Nikolaichuk, A. A., Kartel, N. T., Kupchik, L. A., \& Denisovich, V. A. (2007). Synthesis and properties of biosorbents derived from cellulose-lignin plant materials - waste of agro-industrial complex. Sorbtcionnye i khromatograficheskie protcessy, 7(3), 489-498. [In Russian].

Osadchenko, I. M., Gorlov, I. F., Skachkov, D. A., \& Miakotnykh, A. S. (2007). The method of producing sorbent based on natural polymer. RU Patent № 2302896.

Savvateeva, L. Iu., Kamenev, A. V., \& Kamenev, V. F. (2001). The method of producing sorbent. RU Patent № 2172209.

Suflet, D. M., Chitanu, G. C., \& Popa, V. I. (2006). Phosphorylation of polysaccharides: New results on synthesis and characterization of phosphorylated cellulose. Reactive \& Functional Polymers, 66, 1240-1249. https://doi.org/10.1016/j.reactfunctpolym.2006.03.006

Varghese, A. G., Paul, S. A., \& Latha, M. S. (2018). Cellulose Based Green Adsorbents for Pollutant Removal from Wastewater. In G. Crini, \& E. Lichtfouse (Eds.). Green Adsorbents for Pollutant Removal. Environmental Chemistry for a Sustainable World, 19, 127-157. Springer. https://doi.org/10.1007/978-3-319-92162-4 4

Yerofeyev, V. A., Forostian, Yu. M., \& Kovalev, M. I. (1997). The method of obtaining a universal sorbent. UA Patent № 17174.

Yerofeyev, V. A., Kultenko, E. A., \& Cherkashyna, N. I. (2013). The use of sorbents on the basis of a waste of processing of vegetable raw material in the wastewater treatment and industrial environments. Ekol. bezpeka, 2(16), 89-92. [In Ukrainian].

Yerofeyev, V. A., Kultenko, E. A., \& Pilipchenko, I. I. (2016). The method of obtaining a selective sorbent. RU Patent № 2589484.

Yerofeyev, V. A., Pilipchenko, I. I., \& Cherkashina, N. I. (2011). A method for obtaining a modified organic powder sorbent "Foliox KPM". UA Patent № 93824.

D. O. Yelatontsev' , A. P. Mukhachev' ${ }^{2}$, . I. Suprunchuk ${ }^{3}$

${ }^{1}$ Dniprovsky State Technical University, Kam'ianske, Ukraine

${ }^{2}$ Limited Liability Company "DIYA" Scientific-Innovative Enterprise, Kam'ianske, Ukraine ${ }^{3}$ National Technical University of Ukraine "Igor Sikorsky Kyiv Polytechnic Institute", Kyiv, Ukraine

\section{LIGNOCELLULOSIC SORBENT DERIVED FROM WALNUT SHELL}

Nowadays, more and more green materials, raw or modified, are inclined to be explored instead of conventional adsorbents, within concept of Green Chemistry. Ukraine possess a large stock of agricultural waste withal a variety of ecological problems, caused by extensive water pollution by industry. Low-cost by-products from agricultural, household and industrial sectors have been recognized as a sustainable solution for wastewater treatment. They allow achieving the removal of pollutants from wastewater and at same time $\mathrm{t}$ oContribute to the waste minimization, recovery and reuse. However, adsorption capacities of raw lignocellulosic materials are relatively low, but they can be dramatically increased by means of thermal, physical or chemical activation. In this paper, a list of novel Ukrainian and Russian walnut shell biosorbent literature has been compiled and discussed. After a brief description of walnut shell and its properties and applications, the paper gives a general overview of producing technologies of lignocellulosic sorbents derived from walnut shell media. One of the main points in chemical activation of lignocellulosic materials are such agents as acidic (e.g. $\mathrm{HCl}, \mathrm{HNO}_{3}, \mathrm{H}_{2} \mathrm{SO}_{4}$, and $\mathrm{H}_{3} \mathrm{PO}_{4}$ ), alkaline (e.g. $\mathrm{NaOH}$ and $\mathrm{NaHCO}_{3}$ ), oxidative (like $\mathrm{KMnO}_{4}$ ), metal salt (e.g. $\mathrm{NaCl}, \mathrm{CaCl} 2$, and $\mathrm{MgCl}_{2}$ ), and organic (e.g. formaldehyde, monosodium glutamate, and anionic surfactant). But only few of them can be used in chemical activation processes without producing various types of liquid waste. According to research data and our own experimental results, a combination of phosphoric acid with urea can be considered as the most promising for highly effective modification of lignin and cellulose surface. It was shown, that typical phosphorylation technology of walnut shell can be improved under the next conditions: base $\left(\mathrm{NH}_{4} \mathrm{OH}\right)$ concentration $20 \%$; activation mixture contains $20 \% \mathrm{H}_{3} \mathrm{PO}_{4}, 40 \% \mathrm{CO}\left(\mathrm{NH}_{2}\right)_{2}$ and $40 \% \mathrm{H}_{2} \mathrm{O}$; phosphorylation is conducted at room temperature and continuous stirring. Duration of delignification (base treatment) is $6 \mathrm{~h}$, duration of phosphorylation $-1 \mathrm{~h}$. That conditions ensure a significant resource economy within high physic-chemical properties of obtained lignocellulosic sorbent (SLC): specific volume $-0,6 \mathrm{~cm}^{3} / \mathrm{g}$; porosity $-76 \%$; full static exchange capacity $-1,3 \mathrm{mmol} / \mathrm{cm}^{3}$. Obtained SLC meant to be used for removal of $d$-elements (heavy, radioactive metals) from various types of effluents, drinking water etc.

Keywords: lignin; cellulose; phosphorylation; technological parameters; walnut shell; sorption. 